\title{
Awareness and attitude to the law banning smoking in public places in Osun State, Nigeria
}

\author{
Samuel Anu Olowookere ${ }^{1 *}$, Ebenezer Gbenga Adepoju ${ }^{2}$ and Olalere Omoyosola Gbolahan ${ }^{3}$
}

\begin{abstract}
Objective: This study determined the awareness and attitude towards the Osun state prohibition of smoking in public places law.

Method: Descriptive cross-sectional study design. 520 consenting respondents recruited using a convenience sampling method were interviewed using a semi-structured questionnaire covering their smoking pattern, awareness and attitude towards the law of prohibition of smoking in public places in Osun State. Data analyzed using descriptive and chi-square statistics.

Results: Only 38\% were aware of the law while none had seen the document. Fifty six percent felt cigarette smoking is a problem that required the law to be implemented, while only 20\% agreed that the law will stop tobacco use. The radio (58\%), bill boards (45\%) and newspapers (44\%) were the major sources of awareness of the law. The perception of risk posed to the public and family health by cigarette smoking was poor among the participants.

Conclusion: There is poor awareness and attitude to the law of prohibition of smoking in public places in Osun State. It is necessary to increase sensitization of the general public and enforcement of the law.
\end{abstract}

Keywords: Law on cigarette smoking prohibition, Public places, Osun state, Nigeria

\section{Introduction}

There are about 1.3 billion smokers in the world and approximately $80 \%$ of them live in the developing countries [1]. Previous studies on the burden of tobacco use in Nigeria had reported a prevalence of current smoking as high as $31.9 \%$ in some urban areas and as low as $17.6 \%$ in the rural areas $[2,3]$. A recent study in Osogbo, Osun state reported that $8.7 \%$ of their study participants were current smokers [4]. Various studies in Nigeria and beyond have also suggested a high level of passive smoking in the general population [2-5]. For example, Desalu et al. in 2011 reported $38.8 \%$ of their study population having regular exposure to second hand smoke with $24.4 \%$ from public places [3].

In Nigeria most states do not have a law in place to control smoking in public places [6], and in states where a law exists, such as in Osun state there had been no studies, to our knowledge, that assessed public awareness and

\footnotetext{
* Correspondence: sanuolowookere@yahoo.com

${ }^{1}$ Department of Community Health, College of Health Sciences, Obafemi Awolowo University, lle-lfe, Nigeria

Full list of author information is available at the end of the article
}

attitudes to the law, hence the objective of this study was to determine population awareness and attitudes to the law prohibiting cigarette smoking in public places in Osun state, Nigeria.

\section{Methods}

Study setting

Osun state was created out of old Oyo state by the Nigerian Federal Government on August 27, 1991. It is located in the heartland of Yoruba people in the South west geo-political zone of Nigeria. It shares the distinctive high urbanization attributes of most parts of Yorubaland. It is bounded in the north by Kwara state, in the east partly by Ekiti state and partly by Ondo state and in the west by Oyo state. According to the 2006 population census, Osun state has a population of 3,416,959. The study site is Osogbo, the capital of Osun state. The population of Osogbo by 2006 census is 288,455 . The bill regulating smoking in public places in Osun state was sponsored by the Osun State House of Assembly which was eventually 
signed into law by the Executive Governor on $14^{\text {th }}$ December, 2009.

\section{Sample}

This is a descriptive cross-sectional study. The required sample size of 384 was calculated using an appropriate statistical formula for estimating the minimum sample size in descriptive health studies $[\mathrm{n}=\mathrm{Z} 2 \mathrm{pq} / \mathrm{d} 2]$ and estimated prevalence of cigarette smoking taken as 50\% since it is not exactly known. The minimum sample size was increased by $10 \%$ to take care of incomplete/non response and refusals. A total of 520 consenting respondents were interviewed out of 640 Osogbo residents (response rate 81.3\%) approached to participate in this study. Convenience sampling method was used to enroll these participants during the month of March, 2011. Permission to conduct the study was granted by the Osun State Hospital Ethics and Research Committee. Informed consent was taken from the respondents while they were reassured of the confidentiality of the information obtained.

The respondents included 239 males (46\%) and $281 \mathrm{fe}-$ males (54\%). Their mean age (SD) was 42.2 (12.4) years ranging from 15 to 68 years. Most of the study participants were civil servants (21.4\%) and Transporters (24.8\%). They were interviewed with a pretested semi-structured questionnaire that included questions on their sociodemographic information, smoking patterns, awareness and attitude to the law prohibiting cigarette smoking in public places in Osun State, source of awareness of this law and their opinion about cigarette smoking. The respondents' cigarette smoking status was categorized into 'ever smokers' and 'never smokers'. 'Ever smokers include former and current smokers. 'Current smokers' were respondents who smoked at least a cigarette in the one month prior to the study. 'Former smokers' were reported as those who had smoked for six months but had not smoked for at least one month prior to the study. Those who 'Never smoked' had never smoked a cigarette [4].

\section{Statistical analysis}

Data was entered into and analysed with SPSS version 16. Frequencies and proportions were used to summarise categorical variables, while quantitative data were presented as means and standard deviations. Chi-square statistics were used to determine the strength of association of different factors with their cigarette smoking status. $\mathrm{p}$ values $<0.05$ was considered statistically significant.

\section{Results}

A total of 520 respondents were interviewed: 239 males (47\%), 281 females (53\%), and age range 15 - 68 years (mean $42.2 \pm 12.4$ years). Majority of the respondents were civil servants (21.4\%), Traders (26.5\%) and Transporters (24.8\%). Most had secondary school education and above (70\%) and married (67.4\%). Nineteen percent had ever smoked a cigarette with $8.1 \%$ current smokers (Table 1 ).

Table 2 reported the respondents' awareness and attitude to the Osun state prohibition of smoking in public places. Only $38 \%$ were aware of the law prohibiting tobacco smoking in public places in Osun State while none of the respondents had seen the document. Over

\begin{tabular}{|c|c|}
\hline Characteristics & Frequency $(n=520) N(\%)$ \\
\hline \multicolumn{2}{|l|}{ Age group } \\
\hline $19-29$ & $34(6.6)$ \\
\hline $30-39$ & $134(25.8)$ \\
\hline $40-49$ & $152(29.2)$ \\
\hline 50 and above & $200(38.4)$ \\
\hline \multicolumn{2}{|l|}{ Sex } \\
\hline Male & $239(46)$ \\
\hline Female & $281(54)$ \\
\hline \multicolumn{2}{|l|}{ Marital status } \\
\hline Single & $150(28.8)$ \\
\hline Married & $350(67.4)$ \\
\hline Divorced & $20(3.8)$ \\
\hline \multicolumn{2}{|c|}{ Highest education level } \\
\hline None & $64(12.4)$ \\
\hline Primary & $92(17.6)$ \\
\hline Secondary & $188(36.2)$ \\
\hline Tertiary & $176(33.8)$ \\
\hline \multicolumn{2}{|l|}{ Occupation } \\
\hline Civil servant & $111(21.4)$ \\
\hline Traders & $138(26.5)$ \\
\hline Artisan & $87(16.7)$ \\
\hline Transporters & $129(24.8)$ \\
\hline Unemployed & $55(10.6)$ \\
\hline \multicolumn{2}{|l|}{ Ethnicity } \\
\hline Yoruba & 466 (89.6) \\
\hline Igbo & $23(4.4)$ \\
\hline Others & $31(6.0)$ \\
\hline \multicolumn{2}{|l|}{ Religion } \\
\hline Christianity & $294(56.5)$ \\
\hline Islam & $210(40.4)$ \\
\hline Traditional religion & $16(3.1)$ \\
\hline \multicolumn{2}{|l|}{ Smoking pattern } \\
\hline Current smokers & $42(8.1)$ \\
\hline Former smokers & $57(10.9)$ \\
\hline Never smokers & $421(81.0)$ \\
\hline
\end{tabular}


Table 2 Respondents' awareness and attitude towards the Osun state prohibition of smoking in public places

\begin{tabular}{|c|c|c|c|c|}
\hline \multirow[t]{3}{*}{ Variable } & \multicolumn{2}{|c|}{ Cigarette smoking status } & \multirow{3}{*}{$\begin{array}{l}\text { Total } \\
(n=520)\end{array}$} & \multirow[t]{3}{*}{${ }^{*} p$ value } \\
\hline & Ever (\%) & Never (\%) & & \\
\hline & $\mathrm{n}=99$ & $n=421$ & & \\
\hline
\end{tabular}

Awareness of the no smoking law

$\begin{array}{lllll}\text { Yes } & 28(28.3) & 170(40.4) & 198(38) & 0.026 \\ \text { No } & 71(71.7) & 251(59.6) & 322(62) & \end{array}$

Seen the no smoking law document

$\begin{array}{llll}\text { Yes } & 0(0) & 0(0) & 0(0) \\ \text { No } & 99(19) & 421(81) & 520(100)\end{array}$

The law is needed to control smoking

$\begin{array}{lllll}\text { Yes } & 15(15.2) & 276(65.6) & 291(56) & 0.001 \\ \text { No } & 84(84.8) & 145(34.4) & 229(44) & \end{array}$

Smoking affects public health

\begin{tabular}{lcccc} 
Yes & $16(16.2)$ & $278(66)$ & $294(56.5)$ & 0.001 \\
No & $83(83.8)$ & $143(34)$ & $226(43.5)$ & \\
\multicolumn{4}{l}{ Law will stop } & cigarette smoking \\
Yes & $12(12)$ & $92(22)$ & $104(20)$ & 0.001 \\
No & $23(23)$ & $211(50)$ & $234(45)$ & \\
Don't know & $64(65)$ & $118(28)$ & $182(35)$ & \\
Smokers deserve right to smoke & & & \\
Yes & $59(59.6)$ & $50(11.9)$ & $109(21)$ & 0.001 \\
No & $40(41.4)$ & $371(88.1)$ & $411(79)$ & \\
\hline
\end{tabular}

*chi-square statistic.

$28 \%$ of ever smokers compared with $40.4 \%$ of never smokers were aware of the law $(p=0.026)$. Also, $15.2 \%$ of ever smokers compared with $65.6 \%$ of never smokers believe the law is needed to control cigarette smoking $(\mathrm{p}=0.001)$. Fifty six percent felt cigarette smoking is a problem that required the law whereas $20 \%$ felt that the law will curb cigarette smoking eventually. The majority $(59.6 \%)$ of ever smokers compared with $11.9 \%$ of never smokers believe smokers deserve right to smoke $(p=0.001)$. Although $21 \%$ felt cigarette smokers have the right to smoke, such right should not infringe on other people's right to healthy environment.

Table 3 reported the respondents' opinion towards cigarette smoking. Over 15\% of ever smokers compared with $64.1 \%$ of never smokers agree that smoking is dangerous to health $(\mathrm{p}=0.001) .46 .5 \%$ of ever smokers compared with $29.9 \%$ of never smokers stated that smoking at least one cigarette per day is safe $(\mathrm{p}=0.002)$. Also, $32.3 \%$ of ever smokers compared with $21.1 \%$ of never smokers agree that smokers should not smoke at home $(\mathrm{p}=0.018)$. The majority $(56.5 \%)$ agreed that smoking affects family health; 33\% felt smoking 1 cigarette sticks or more per day is safe. Only $20.4 \%$ agreed there should be smoke free areas in public places whereas $23 \%$ felt smokers should not smoke at home.
Table 3 Respondents' opinion on cigarette smoking

\begin{tabular}{|c|c|c|c|c|}
\hline \multirow[t]{3}{*}{ Variable } & \multicolumn{2}{|c|}{ Cigarette smoking status } & \multirow{3}{*}{$\begin{array}{l}\text { Total (\%) } \\
\mathrm{N}=520\end{array}$} & \multirow[t]{3}{*}{${ }^{*} p$ value } \\
\hline & \multirow{2}{*}{$\begin{array}{l}\text { Ever (\%) } \\
\mathrm{n}_{1}=99\end{array}$} & Never (\%) & & \\
\hline & & $\mathrm{n}_{2}=421$ & & \\
\hline \multicolumn{5}{|c|}{ Smoking is harmful to health } \\
\hline Agree & $15(15.2)$ & $271(64.1)$ & $286(55)$ & \multirow[t]{2}{*}{$78.452 ; 0.001$} \\
\hline Disagree & $84(84.8)$ & $150(35.9)$ & $234(45)$ & \\
\hline \multicolumn{5}{|c|}{ Number of cigarette stick safe } \\
\hline None & $53(53.5)$ & $295(70.1)$ & $348(67)$ & \multirow[t]{2}{*}{$9.901 ; 0.002$} \\
\hline$\geq 1$ & $46(46.5)$ & $126(29.9)$ & $172(33)$ & \\
\hline \multicolumn{5}{|c|}{ Smoke free environment is necessary } \\
\hline Agree & $26(26.3)$ & $80(19)$ & $106(20.4)$ & \multirow[t]{2}{*}{$2.603 ; 0.107$} \\
\hline Disagree & 73(73.7) & $341(81)$ & $414(79.6)$ & \\
\hline \multicolumn{5}{|c|}{ Smokers should not smoke at home } \\
\hline Agree & $32(32.3)$ & $89(21.1)$ & $121(23.2)$ & \multirow[t]{2}{*}{$5.614 ; 0.018$} \\
\hline Disagree & $67(67.7)$ & $332(78.9)$ & $399(76.8)$ & \\
\hline
\end{tabular}

Table 4 reported the respondents sources of awareness of the Osun state prohibition of smoking in public places. The radio (58\%), bill boards (45\%) and newspapers $(44 \%)$ were the commonest sources of information about the law in Osun state.

\section{Discussion}

This population based study assessed the awareness and attitude of the respondents to the Osun state prohibition of smoking in public places. It reported low awareness among respondents with the radio as the main source of awareness. It should however been noted that the radio remains the commonest source of general awareness among this population making it a very important route of communication with the populace. Hence policy makers need to make use of such medium to inform, educate and communicate to the general public about this law.

Table 4 Sources of awareness of the Osun state prohibition of smoking in public places

\begin{tabular}{ll}
\hline *Sources of awareness & Frequency $(\mathbf{n}=\mathbf{1 9 8}) \mathbf{N}(\%)$ \\
\hline Radio & $115(58)$ \\
Bill board/poster/leaflet & $89(45)$ \\
Newspapers & $87(44)$ \\
Health workers & $73(37)$ \\
Television & $69(35)$ \\
Friends & $45(23)$ \\
School & $26(13)$ \\
Internet & $8(4)$ \\
No response & $6(3)$ \\
\hline
\end{tabular}

*Multiple responses. 
Studies had showed that smoking is the most important avoidable cause of premature morbidity and mortality in the world $[1,5]$. This study reported about onefifth of respondents were ever smokers. Several studies in Nigeria had reported similar finding [6].

Over three fifth of the respondents were not aware of the law prohibiting smoking in public places while none of the study participant had read the actual document. This situation can make it difficult for the legislation in public places to be effective therefore, it is essential that there is more sensitization of the general public or else the chances of failure remain high. It is therefore important to disseminate information about the law in order to eliminate smoking in public places. Its proper implementation and enforcement will further reduce tobacco induced diseases in this study environment $[5,7]$.

While the majority felt that the law prohibiting cigarette smoking in public places in Osun State is necessary, fewer smokers saw the necessity of this law in protecting both their and public health. In fact, some smokers felt that the law cannot stop smoking in public places and that smokers deserve the right to smoke wherever they like at anytime. These views expressed by the smoking population contradict the general opinion of non smokers. This further showed the need to enhance awareness and support enforcement of the law. Previous studies had reported that few states in the country have adopted the law, therefore its successful implementation lies on both the government and the citizens; the power to implement and enforce the law lies with the government while the will power to embrace and obey the law lies with the citizens [5].

Some of the smokers in our study believed that cigarette smoking is not dangerous to their health. This view needs consideration as it implies that these smokers are either unknowingly or carelessly endangering their life but that of their close family members, co-workers and neighbours. Also, only a few smokers felt a smoke free environment is necessary. This calls for urgent attention in order to reduce the effects of tobacco exposure among this population. There is urgent need for more public education in Osun state and beyond on the danger of cigarette use in both the smoking and non smoking population.

To the best of our knowledge, this is the first study performed to assess the awareness and attitude of Osogbo residents to the Osun state prohibition of smoking in public places law. We were also unable to identify other studies done to assess such law in operation in other states in Nigeria. A limitation is the use of the convenience sampling technique to select the study population, which limits its generalizability to the population of the State or Nigeria in general. This was done to ensure a proportionate increase in the smoking population among the selected respondents.
In conclusion, the present level of awareness of the law prohibiting cigarette smoking in public places in Osun state was poor. It is recommended that strategies to increase the present level of public awareness on dangers of cigarette smoking and enforcement of the law of prohibition of smoking in public places should be put in place. These strategies will include awareness creation activities in public places, bill boards, jingles on the radio and other mass media venues.

\section{Competing interest}

The authors disclose no potential conflicts of interest.

\section{Authors' contributions}

AEG and OSA made substantial contributions to conception and design of the study while all the authors were involved in data collection, analysis and interpretation. All authors were involved in writing the manuscript and approved the final copy.

\section{Acknowledgement}

The authors thank the entire staff of Department of Preventive Medicine, State Specialist Hospital, Osogbo for their support and cooperation during the study period.

\section{Short report}

There is poor awareness and attitude to the law banning cigarette smoking in public places in Osun state, Nigeria. Also, the perception of risk posed to the public and family health by cigarette smoking was poor. Sensitization of the general public and enforcement of the law is essential.

\section{Author details}

'Department of Community Health, College of Health Sciences, Obafemi Awolowo University, Ile-Ife, Nigeria. ${ }^{2}$ Department of Preventive Medicine, State Specialist Hospital, Asubiaro, Osogbo, Osun-State, Nigeria. ${ }^{3}$ Department of Oral and Maxillofacial Surgery, University of Ibadan, Ibadan, Nigeria.

Received: 27 December 2013 Accepted: 21 March 2014

Published: 27 March 2014

\section{References}

1. The Global Tobacco Surveillance System. The GTSS. http://www.cdc.gov/ tobacco/global/gtss/tobacco_atlas/pdfs/tobacco_atlas.pdf.

2. Ayankogbe OO, Inem OA, Bamgbala OA, Robert OA: Attitudes and determinant of cigarette smoking among rural dwellers South West. Nigeria Niger Med Pract 2003, 44:70-74.

3. Desalu OO, Onyedum CC, Adewole OO, Fawibe AE, Salami AK: Secondhand smoke exposure among nonsmoking adults in two Nigerian cities. Ann Afr Med 2011, 10:103-111.

4. Adepoju EG, Olowookere SA, Afolabi OT, Olajide FO, Aluko OO: A population based study on the prevalence of cigarette smoking and smokers' characteristics at Osogbo, Nigeria. Tobacco Use Insights 2013, 6:1-5. doi:10.4137/TUI.S10763

5. Callinan JE, Clarke A, Doherty K, Kelleher C: Legislative smoking bans for reducing second hand smoke exposure, smoking prevalence and tobacco consumption. Cochrane Database Syst Rev 2010, 4(Art. No): CD005992. doi:10.1002/14651858.CD005992.pub2.

6. Agaku I, Akinyele A, Oluwafemi A: Tobacco control in Nigeria- policy recommendations. Tob Induced Dis 2012, 10:8.

7. Adejuwon GA: Tobacco use and second hand smoke as risk factors for diseases in Nigeria: implications for collaborative research and multilevel tobacco control strategies. Afr J Med Med Sci 2009, 38(Suppl 2):21-29.

doi:10.1186/1617-9625-12-6

Cite this article as: Olowookere et al: Awareness and attitude to the law banning smoking in public places in Osun State, Nigeria. Tobacco Induced Diseases 2014 12:6. 